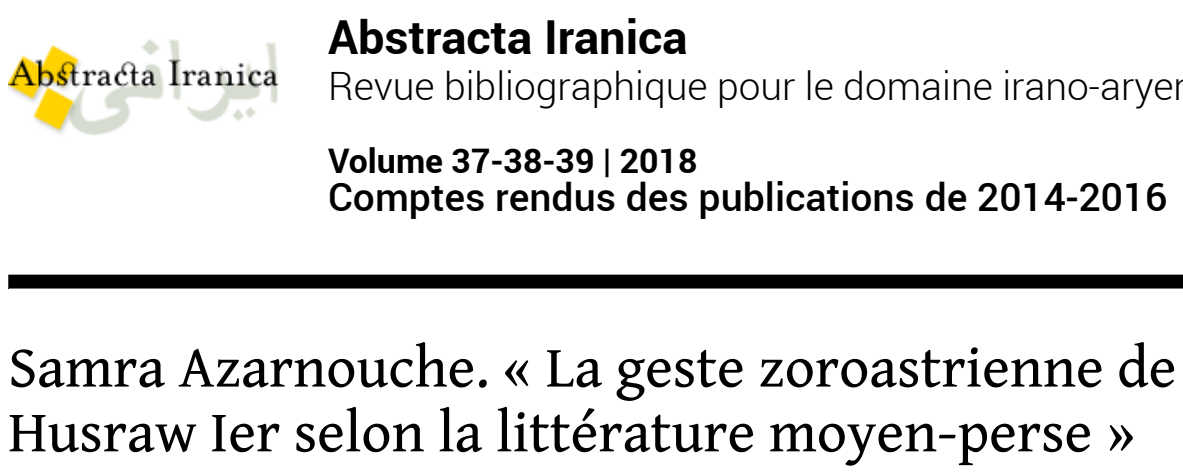

Alessia Zubani

OpenEdition

12 Journals

Édition électronique

URL : http://journals.openedition.org/abstractairanica/45793

DOI : 10.4000/abstractairanica.45793

ISBN : 1961-960X

ISSN : 1961-960X

Éditeur :

CNRS (UMR 7528 Mondes iraniens et indiens), Éditions de l'IFRI

Référence électronique

Alessia Zubani, « Samra Azarnouche. « La geste zoroastrienne de Husraw ler selon la littérature moyen-perse » », Abstracta Iranica [En ligne], Volume 37-38-39 | 2018, document 23, mis en ligne le 30 décembre 2018, consulté le 02 octobre 2020. URL : http://journals.openedition.org/abstractairanica/ 45793 ; DOI : https://doi.org/10.4000/abstractairanica.45793

Ce document a été généré automatiquement le 2 octobre 2020.

Tous droits réservés 


\title{
Samra Azarnouche. " La geste zoroastrienne de Husraw Ier selon la littérature moyen-perse »
}

\author{
Alessia Zubani
}

\section{RÉFÉRENCE}

Samra Azarnouche. « La geste zoroastrienne de Husraw Ier selon la littérature moyenperse » in Christelle Jullien (éd.). Husraw Ier. Reconstructions d'un règne. Sources et documents. Paris : Association pour l'avancement des études iraniennes, 2015, p.

235-255.

1 Cet article est consacré aux attestations sur la figure de Husraw Ier dans la littérature zoroastrienne moyen-perse. De typologies différentes, elles peuvent se référer à des allusions historiques, récits fictifs, andarz (mots de sagesse) ou apologies religieuses. L'analyse textuelle révèle une image de Husraw - probablement fruit des efforts propagandistes du roi lui-même et de son entourage - comme souverain archétypal. De ces sources Husraw Ier n'émerge pas seulement comme homme politique et grand réformateur au niveau administratifs et militaire, mais il incarne aussi les attributs du paladin de la Dēn, la Bonne Religion. Dans cette optique, les éléments qui accompagnent Husraw dans les narrations assument une valeur spécifique : le roi est assisté par la figure de son sage conseiller Wuzurg-Mihr dans ses efforts pour restaurer la Dēn et dans la lutte contre les adversaires hérétiques, où Mazdak représente l'ennemi par excellence.

Une annexe des sources moyen-perse citées, parmi lequel figure un ouvrage inédit, complète l'article, en transcription et traduction française. 


\section{AUTEURS}

\section{ALESSIA ZUBANI}

Doctorante EPHE, Mondes iranien et indien, Paris 